\title{
Agonist-Induced Internalization of Serotonin-1A Receptors in the Dorsal Raphe Nucleus (Autoreceptors) But Not Hippocampus (Heteroreceptors)
}

\author{
Mustapha Riad,, ${ }^{1}$ Kenneth C. Watkins, ${ }^{1}$ Edith Doucet, ${ }^{2}$ Michel Hamon, ${ }^{2}$ and Laurent Descarries ${ }^{1}$ \\ ${ }^{1}$ Départements de Pathologie et Biologie Cellulaire et de Physiologie, and Centre de Recherche en Sciences \\ Neurologiques, Faculté de Médecine, Université de Montréal, Montreal, Quebec, Canada H3C 3J7, and 2Institut National \\ de la Santé et de la Recherche Médicale U288, Neuropsychopharmacologie, Faculté de Médecine Pitié-Salpêtrière, \\ 75634 Paris Cedex 13, France
}

Serotonin-1A $\left(5-\mathrm{HT}_{1 \mathrm{~A}}\right)$ receptors in the CNS are a major target for psychotropic drugs. In nucleus raphe dorsalis (NRD) and hippocampus (CA3), the selective 5- $\mathrm{HT}_{1 \mathrm{~A}}$ agonist (+)-8hydroxy-2-(di- $N$-propylamino) tetralin (8-OH-DPAT) reduces the firing activity of serotoninergic $(5-\mathrm{HT})$ and pyramidal neurons, respectively. When located on 5-HT (autoreceptors), but not on non-5-HT (heteroreceptors) neurons, 5- $\mathrm{HT}_{1 \mathrm{~A}}$ receptors are known to be subject to desensitization. Using quantitative electron microscopy after pre-embedding immunogold labeling with specific antibodies, we examined the subcellular distribution of these receptors after acute administration of 8-OH-DPAT $(0.5 \mathrm{mg} / \mathrm{kg}$, i.v.). Silver-intensified immunogold particles associated with the plasma membrane or the cytoplasm were counted in somata and dendrites within the NRD, $15 \mathrm{~min}, 1 \mathrm{hr}$ and $24 \mathrm{hr}$ after 8-OH-DPAT injection, and in hippocampal dendrites $1 \mathrm{hr}$ after the same treatment. Significant decrease in the density of membrane labeling and concomitant increase of

Preclinical and clinical studies suggest that central serotonin [5-hydroxytryptamine (5-HT)] neurotransmission and modulation is involved in the etiology and treatment of anxiety and depression (Murphy, 1990; Blier and de Montigny, 1999). The discovery of multiple 5-HT receptor subtypes and development of various selective ligands for these receptors have provided an opportunity to clarify the role or roles of 5-HT in these mental disorders, and thus eventually contribute to the design of more effective treatments. Among 5-HT receptors, the 5- $\mathrm{HT}_{1 \mathrm{~A}}$ subtype is of particular interest because of its well established role in the regulation of emotional and behavioral processes (Blier and de Montigny, 1994; Artigas et al., 1996; Ramboz et al., 1998). Thus, the prototypical $5-\mathrm{HT}_{1 \mathrm{~A}}$ agonist $(+)-8$-hydroxy-2-(di- $N$-propylamino) tetralin (8-OH-DPAT), exhibits clear-cut anxiolytic(Carli and Samanin, 1988; Picazo et al., 1995; Remy et al., 1996) and antidepressant-like (Kennett et al., 1987a; Martin et al., 1990) properties in animal models.

\footnotetext{
Received June 12, 2001; revised Aug. 16, 2001; accepted Aug. 23, 2001.

This work was supported by Grant MT-3544 from the Medical Research Council of Canada to L.D. (now NRF 3544 from Canadian Institutes of Health Research) and an Institut National de la Santé et de la Recherche Médicale grant to M.H. We thank Gaston Lambert and Jean Léveillé for expert photographic work.

Correspondence should be addressed to Dr. Laurent Descarries, Département de Pathologie et Biologie Cellulaire, Faculté de Médecine, Université de Montréal, CP 6128, Succursale Centreville, Montréal, Quebec, Canada H3C 3J7. E-mail: laurent.descarries@umontreal.ca.

Copyright (ㄷ) 2001 Society for Neuroscience $0270-6474 / 01 / 218378-09 \$ 15.00 / 0$
}

cytoplasmic labeling were demonstrated in the NRD, 15 min and $1 \mathrm{hr}$ after 8-OH-DPAT administration, with a return to baseline level at $24 \mathrm{hr}$. Internalization was blocked by previous administration of the 5- $\mathrm{HT}_{1 \mathrm{~A}}$ antagonist $\mathrm{N}$-[2-[4-(2-methoxyphenyl)-1-piperazinyl]ethyl]-N-(2-pyridinyl) cyclohexane-carboxamide (WAY 100635), which, by itself, was without apparent effect. In hippocampus (CA3), there were no apparent changes in the distribution of the receptor after 8-OH-DPAT administration. These findings are in line with earlier results showing a desensitization of $5-\mathrm{HT}_{1 \mathrm{~A}}$ autoreceptors but not heteroreceptors after treatment with $5-\mathrm{HT}_{1 \mathrm{~A}}$ receptor agonist. They suggest that this desensitization is the result of autoreceptor internalization.

Key words: agonist; 5-HT ${ }_{1 A}$ receptors; desensitization; internalization; serotonin; 8-OH-DPAT; nucleus raphe dorsalis; hippocampus; immunocytochemistry

Whether located on serotoninergic neurons (autoreceptors) or on other neurons (heteroreceptors), the $5-\mathrm{HT}_{1 \mathrm{~A}}$ receptors mediate inhibition of neuronal firing (for review, see Barnes and Sharp, 1999). In the nucleus raphe dorsalis (NRD), their activation by 8-OH-DPAT suppresses the discharge of serotoninergic neurons (Sprouse and Aghajanian, 1986; Blier and de Montigny, 1990), reduces 5-HT turnover and synthesis (Hamon et al., 1988; Hjorth and Magnusson, 1988), and therefore inhibits 5-HT release within the NRD itself and its territories of projection (Sharp et al., 1989a,b; Invernizzi et al., 1991; Bonvento et al., 1992).

Several studies have demonstrated that acute treatment with 8-OH-DPAT produces a desensitization of NRD 5-HT 1 A autoreceptors (Kennett et al., 1987b; Beer et al., 1990; Seth et al., 1997). Rapid desensitization of $5-\mathrm{HT}_{1 \mathrm{~A}}$ receptors by agonist has also been described in various transfected cell lines (Nebigil et al., 1995; Rotondo et al., 1997; Della Rocca et al., 1999).

In many transmitter-defined neuronal systems, internalization of G-protein-coupled receptors results from their activation by agonists (e.g., dopamine D1, Dumartin et al., 1998; muscarinic $\mathrm{m} 2$ and m4, Bernard et al., 1998, 1999; $\mu$-opioid, Sternini et al., 1996; neurotensin, Faure et al., 1995; somatostatin 2A, Boudin et al., 2000; and substance P, Mantyh et al., 1995). Among 5-HT receptors, such internalization has thus far been described only for the $5-\mathrm{HT}_{2 \mathrm{~A}}$ subtype, but in great detail, in vivo as well as in vitro (Berry et al., 1996; Bhatnagar et al., 2001). Whether it 
actually corresponds to a regulatory mechanism for this receptor is still an open question, however, because both $5-\mathrm{HT}_{2 \mathrm{~A}}$ agonists and antagonists can trigger $5-\mathrm{HT}_{2 \mathrm{~A}}$ receptor internalization (Berry et al., 1996; Willins et al., 1999).

The present study was aimed at determining whether internalization of $5-\mathrm{HT}_{1 \mathrm{~A}}$ receptors occurs in the $\mathrm{NRD}$, in which these autoreceptors desensitize after acute treatment with $8-\mathrm{OH}-$ DPAT. For this purpose, we used a quantitative electron microscopic approach after immunogold labeling with specific anti-5$\mathrm{HT}_{1 \mathrm{~A}}$ receptor antibodies (El Mestikawy et al., 1990; Riad et al., 1991). Experiments were also performed with the selective 5-HT antagonist $\quad N$-[2-[4-(2-methoxyphenyl)-1-piperazinyl]ethyl]- $N$-(2pyridinyl) cyclohexane-carboxamide (WAY 100635), in view of the previous data obtained on $5-\mathrm{HT}_{2 \mathrm{~A}}$ receptors (see above). In all conditions, the fate of $5-\mathrm{HT}_{1 \mathrm{~A}}$ receptors was also examined in the hippocampus, in which, contrary to the NRD, there is no apparent desensitization on acute or chronic stimulation of these heteroreceptors (Kennett et al., 1987b; Le Poul et al., 2000).

\section{MATERIALS AND METHODS}

Drugs. 8-OH-DPAT and WAY 100635 were obtained from Research Biochemicals (Natick, MA).

Antibodies. The preparation and characterization of rabbit polyclonal antibodies intended for the specific immunocytochemical visualization of $5-\mathrm{HT}_{1 \mathrm{~A}}$ receptors in rat CNS tissues have already been described in detail (El Mestikawy et al., 1990; Riad et al., 1991). These antibodies were raised against a synthetic peptide corresponding to residues 243268 of the predicted amino acid sequence of the third cytoplasmic loop of $5-\mathrm{HT}_{1 \mathrm{~A}}$ receptor in rat. This particular sequence was chosen because it is highly selective for the $5-\mathrm{HT}_{1 \mathrm{~A}}$ receptor among all members identified so far within the G-protein-coupled receptor (GPCR) superfamily. For the present study, the antibodies were affinity-purified using immobilized peptide identical to the antigen (Hillion et al., 1994).

Treatments. All experiments abided by the policies and guidelines of the Canadian Council on Animal Care and the regulations of the Animal Care Committee at the Université de Montréal.

Adult male Sprague Dawley rats (Charles River, St. Constant, Quebec, Canada; body weight: $250 \pm 50 \mathrm{gm}$ ) were anesthetized with sodium pentobarbital $(65 \mathrm{mg} / \mathrm{kg}$, i.p.), and a jugular vein was cannulated with a polyethylene catheter for intravenous administration of drugs. All animals fully recovered from this procedure within a few hours. Four days later, the rats were injected intravenously with either: (1) saline $(0.9 \%$ $\mathrm{NaCl}$ ); (2) the $5-\mathrm{HT}_{1 \mathrm{~A}}$ receptor agonist $8-\mathrm{OH}-\mathrm{DPAT}$ (Gozlan et al., 1983), $0.5 \mathrm{mg} / \mathrm{kg}$; (3) the $5-\mathrm{HT}_{1 \mathrm{~A}}$ receptor antagonist WAY 100635 (Gozlan et al., 1995) $1 \mathrm{mg} / \mathrm{kg}, 10 \mathrm{~min}$ before 8-OH-DPAT; or (4) WAY $100635(1 \mathrm{mg} / \mathrm{kg})$. The drugs were dissolved in saline to be injected in a volume of $1 \mathrm{ml} / \mathrm{kg}$. As previously described (Smith and Peroutka, 1986), hindlimb extension and a flattened body posture were observed after 8-OH-DPAT.

Tissue preparation. Fifteen minutes, $1 \mathrm{hr}$, or $24 \mathrm{hr}$ after saline or drug injection, the rats were deeply anesthetized with sodium pentobarbital $(80 \mathrm{mg} / \mathrm{kg}$, i.p.), and perfused through the aortic arch with a solution of $3.5 \%$ acrolein and $2 \%$ paraformaldehyde (PFA) in $0.1 \mathrm{~m}$ phosphate buffer $(\mathrm{PB}), \mathrm{pH} 7.4$, at room temperature. The brain was then removed and sliced into 1-mm-thick transverse slabs, which were post-fixed by immersion for $2 \mathrm{hr}$ in the $2 \%$ PFA solution at $4{ }^{\circ} \mathrm{C}$ and washed in PBS $(0.9 \% \mathrm{NaCl}$ in $50 \mathrm{~mm} \mathrm{~PB}, \mathrm{pH} 7.4)$. Vibratome sections, $50-\mu \mathrm{m}$-thick, were then cut in cooled PBS, immersed in $0.1 \%$ sodium borohydride in PBS for $30 \mathrm{~min}$ (room temperature), and washed in this buffer before immunocytochemical processing.

Immunocytochemistry. All steps were performed at room temperature. Free-floating sections were sequentially incubated in: (1) a blocking solution of PBS containing $10 \%$ normal goat serum and $0.5 \%$ fish gelatin to saturate nonspecific sites (2 hr); (2) a 1:1000 dilution of anti-5- $\mathrm{HT}_{1 \mathrm{~A}}$ antiserum in blocking solution (48 hr); and (3) a 1:50 dilution of goat anti-rabbit IgGs conjugated to $1 \mathrm{~nm}$ colloidal gold particles (AuroProbe One; Amersham, Oakville, Ontario, Canada) in blocking solution $(2 \mathrm{hr})$. The sections were rinsed in PBS $(3 \times 10 \mathrm{~min})$, then in $2 \%$ sodium acetate $(2 \times 10 \mathrm{~min})$ and treated for $15-18 \mathrm{~min}$ with a silver enhancing kit (IntenSE; Amersham). This reaction was stopped by washing in $2 \%$ sodium acetate followed by PBS. Immunocytochemical controls included
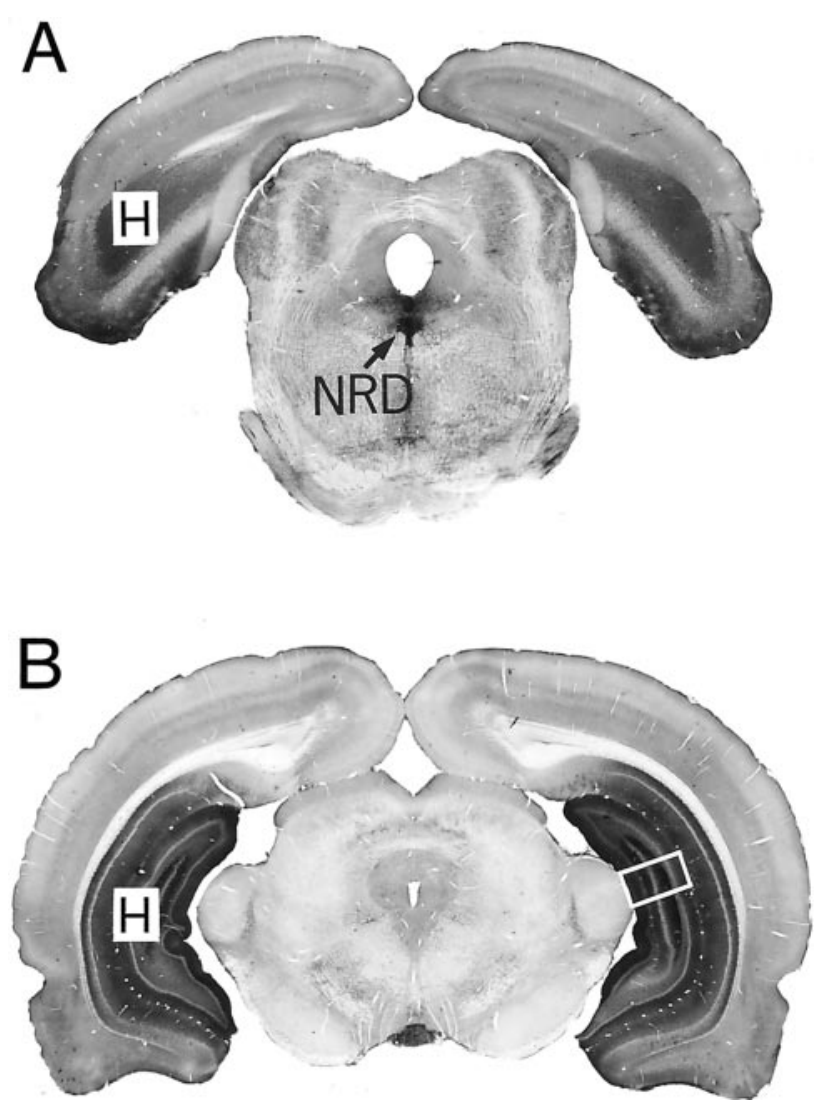

Figure 1. Macrophotographs of 5- $\mathrm{HT}_{1 \mathrm{~A}}$-immunostained, immunoperoxidase-labeled transverse sections showing the areas selected for quantitative electron microscopic analysis of the subcellular distribution of the $5-\mathrm{HT}_{1 \mathrm{~A}}$ receptors in nucleus raphe dorsalis (NRD in $\left.A\right)$ and CA3 area of hippocampus ( framed area in $B$ ). In the NRD, note the stronger labeling of the medioventral portion of the nucleus, as opposed to its mediodorsal portion and lateral wings. In the hippocampus proper and area dentata $(H)$, the layered pattern results essentially from the selective labeling of somata and dendrites of the pyramidal and granular neurons. Magnification, $5 \times$.

sections processed as above except for omission of the primary antibodies or their replacement by preimmune rabbit serum at the same dilution. In all experiments aimed at quantifying the distribution of the receptors, at $1 \mathrm{hr}$ or various time intervals $(15 \mathrm{~min}, 1 \mathrm{hr}, 24 \mathrm{hr}$ ) after drug injection, tissue from a saline-injected control was always processed together with treated rat tissue.

Electron microscopy. The sections were successively rinsed in $\mathrm{PB}$, post-fixed for $30 \mathrm{~min}$ in $1 \%$ osmium tetroxide in PB, washed in PB (3 $\times$ $10 \mathrm{~min}$ ), dehydrated through a graded series of ethanol solutions followed by propylene oxide, infiltrated with Durcupan overnight, and flat-embedded in this resin between a glass slide and a plastic coverslip. After $48 \mathrm{hr}$ of polymerization at $60^{\circ} \mathrm{C}$, the coverslips were removed, and the regions of interest, selected by light microscopy, were excised from the slides and glued to the tip of resin blocks. Ultrathin sections were cut using an ultramicrotome) collected on bare square-meshed copper grids, stained with lead citrate, and examined in the electron microscope (Philips CM100; $60 \mathrm{KV}$ ).

Quantitative analysis. The subcellular distribution of the immunogold labeling was quantified in the NRD (autoreceptors) and/or the CA3 area of the hippocampus (heteroreceptors). In NRD (24 rats), a medioventral portion of the nucleus was examined, at a mesencephalic level corresponding approximately to interaural A $1.36 \mathrm{~mm}$ in the stereotaxic atlas of Paxinos and Watson (1986) (Fig. 1A). In the hippocampus (six rats), the focus was on a vertical portion of the CA3 sector of Ammon's horn and adjacent medial and lateral blades of the dentate gyrus, at a transverse level equivalent to A $2.96 \mathrm{~mm}$ (interaural) in the stereotaxic atlas of Paxinos and Watson (1986) (Fig. 1B). In a first series of experiments, in which the survival time was $1 \mathrm{hr}$, the NRD was examined in seven 


\begin{tabular}{|c|c|c|}
\hline \multicolumn{3}{|c|}{$\begin{array}{l}\text { Table 1. Proportion }(\%) \text { of } 5-\mathrm{HT}_{1 \mathrm{~A}} \text { autoreceptor labeling associated } \\
\text { with the plasma membrane of somata and dendrites in the NRD, as } \\
\text { quantified by counts of silver-intensified immunogold particles in } \\
\text { electron micrographs of tissue fixed } 1 \mathrm{hr} \text { after treatment with } 5-\mathrm{HT}_{1 \mathrm{~A}} \\
\text { agonist and/or antagonist }\end{array}$} \\
\hline & Somata & Dendrites \\
\hline Control $(n=8)$ & $67 \pm 2$ & $86 \pm 1$ \\
\hline 8-OH-DPAT $(n=6)$ & $44 \pm 2 *$ & $53 \pm 1^{*}$ \\
\hline WAY $100635+8$-OH-DPAT $(n=5)$ & $69 \pm 2$ & $89 \pm 3$ \\
\hline WAY $100635(n=3)$ & $68 \pm 1$ & $88 \pm 3$ \\
\hline
\end{tabular}

Means ( \pm SEM) from three to eight rats $(n)$ per group. Treatments as described in Materials and Methods. The membrane compartment was defined by attributing a thickness of $30 \mathrm{~nm}$ (average diameter of the silver-intensified immunogold particles) to the membrane of labeled somata (perikarya) and dendrites. The results were tabulated as actual number of particles in the membrane, as opposed to the cytoplasmic compartment (details in Materials and Methods), and then expressed as percentage of total number (membrane + cytoplasm). In all groups, the membrane compartment represented $3-4 \%$ of the total area examined for somata and $6-7 \%$ for dendrites.

${ }^{*} p<0.001$ by two-way ANOVA followed by Student's $t$ test.

saline controls, five rats treated with 8-OH-DPAT, five rats treated with WAY $100635+8-O H-D P A T$, and three rats treated with WAY 100635 alone. In a second series, the time course of the 8-OH-DPAT effect was investigated in four rats: one control and one rat each killed at $15 \mathrm{~min}, 1$ $\mathrm{hr}$ and $24 \mathrm{hr}$ after injection. The hippocampus was examined in three of the controls and three of the 8-OH-DPAT-treated rats killed $1 \mathrm{hr}$ after injection.

More than 1000 electron micrographs were taken, at working magnifications ranging from $17,000 \times$ to $25,000 \times$. The silver-intensified immunogold particles were counted over 172 sections of cell bodies (controls, 55; 8-OH-DPAT, 60; WAY 100635 + 8-OH-DPAT, 27; WAY 100635, 30) and 852 sections of dendrites (controls, 378; 8-OH-DPAT, 239; WAY 100635 + 8-OH-DPAT, 124; WAY 100635, 111) in NRD, and 141 sections of dendrites (controls, 69; 8-OH-DPAT, 72) in hippocampus.

Two cellular compartments were defined: a membrane compartment, corresponding to a narrow zone, 30 -nm-thick (the average size of the immunogold particles), underneath the plasma membrane, and a cytoplasmic compartment comprising the rest of the perikaryal or dendritic cytoplasm. The diameter and perimeter of the labeled profiles were measured with the aid of a computerized image analysis system (NIH Image 1.60), and the results were expressed as labeling density (number of particles per surface unit) for both the membrane and the cytoplasmic compartments. A total of 8951 particles were counted: 8205 in NRD (5919 in the plasma membrane and 2286 in the cytoplasmic compartment), and 746 in hippocampus (630 in the plasma membrane and 116 in the cytoplasmic compartment).

To define further the subcellular distribution of the receptors after 8-OH-DPAT treatment, the number of immunogold particles associated with large, endosome-like, vesicular profiles (Dumartin et al., 1998) in the cytoplasmic compartment of NRD perikarya was determined in four treated rats and four paired controls. Corresponding results were expressed as a percentage of the total number of particles in the cytoplasmic compartment.

Statistics. The quantitative data on the distribution of the receptors in plasma membrane versus cytoplasmic compartment of NRD somata and dendrites and hippocampal dendrites (means \pm SEM) were expressed as number of particles per unit of surface (Table 1) or as percentage of respective control value in the membrane compartment (see Figs. 4, 5, and 7). Treatment effects were assessed using an ANOVA followed by Student's $t$ test. The effect of 8-OH-DPAT on the association of receptors with endosome-like structures was analyzed by a paired $t$ test. Differences were considered significant if $p<0.05$.

\section{RESULTS}

\section{Nucleus raphe dorsalis}

In keeping with our previous description in normal rats (Riad et al., 2000), the 5-HT $\mathrm{HA}_{1 \mathrm{~A}}$ immunogold labeling was much stronger in the plasma membrane than cytoplasmic compartment of somata and dendrites in the NRD of saline-injected controls (Figs. $2 A$,

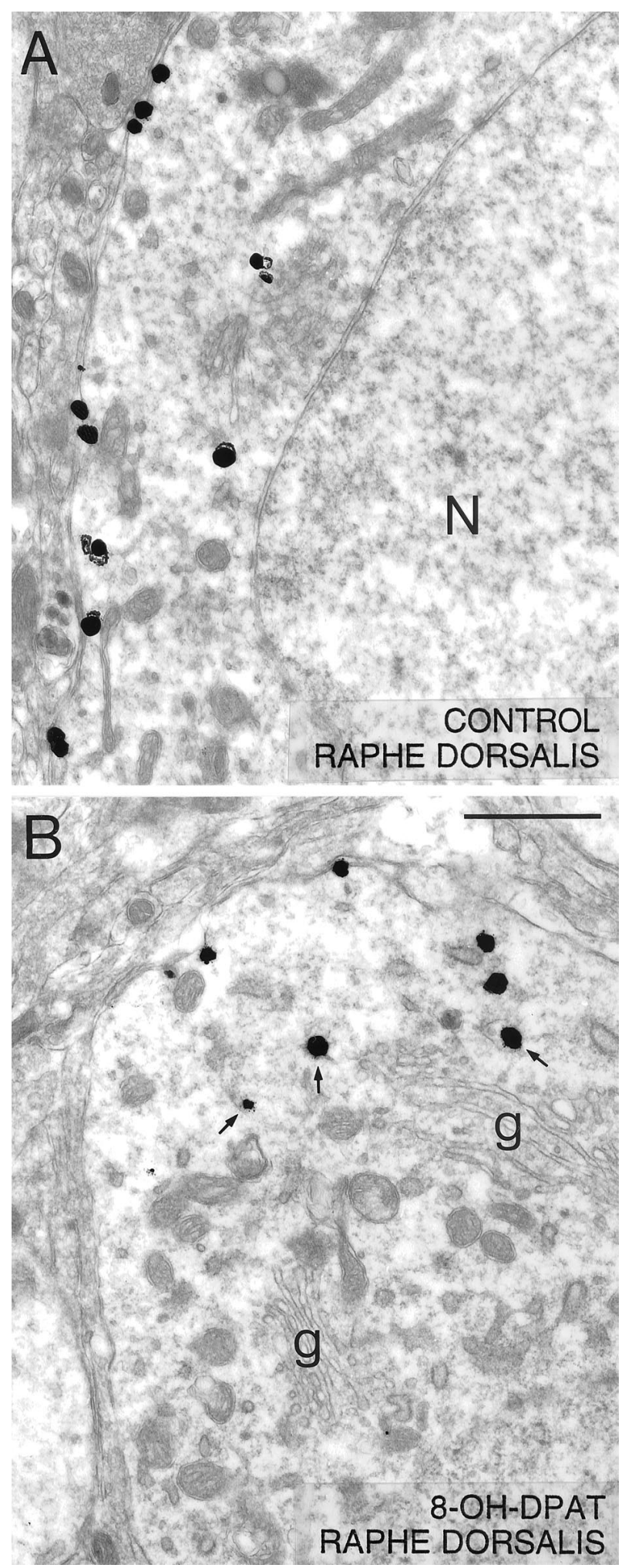

Figure 2. Low-power electron micrographs illustrating the distribution of 5- $\mathrm{HT}_{1 \mathrm{~A}}$ immunoreactivity (immunogold-labeled) in neuronal somata from the NRD of a saline-control $(A)$ and a rat treated with 8-OH-DPAT $1 \mathrm{hr}$ before fixation $(B)$. In the control, note how a majority of the silver-intensified immunogold particles are associated with the plasma membrane as opposed to the cytoplasm of the labeled neuron $(N$ in nucleus), whereas the opposite is true after 8-OH-DPAT treatment [Golgi apparatus $(g)]$. In the treated rat, note the association of some of the cytoplasmic particles with endosome-like profiles (arrows). Scale bar, 1 $\mu \mathrm{m}$. Magnification, $18,000 \times$. 

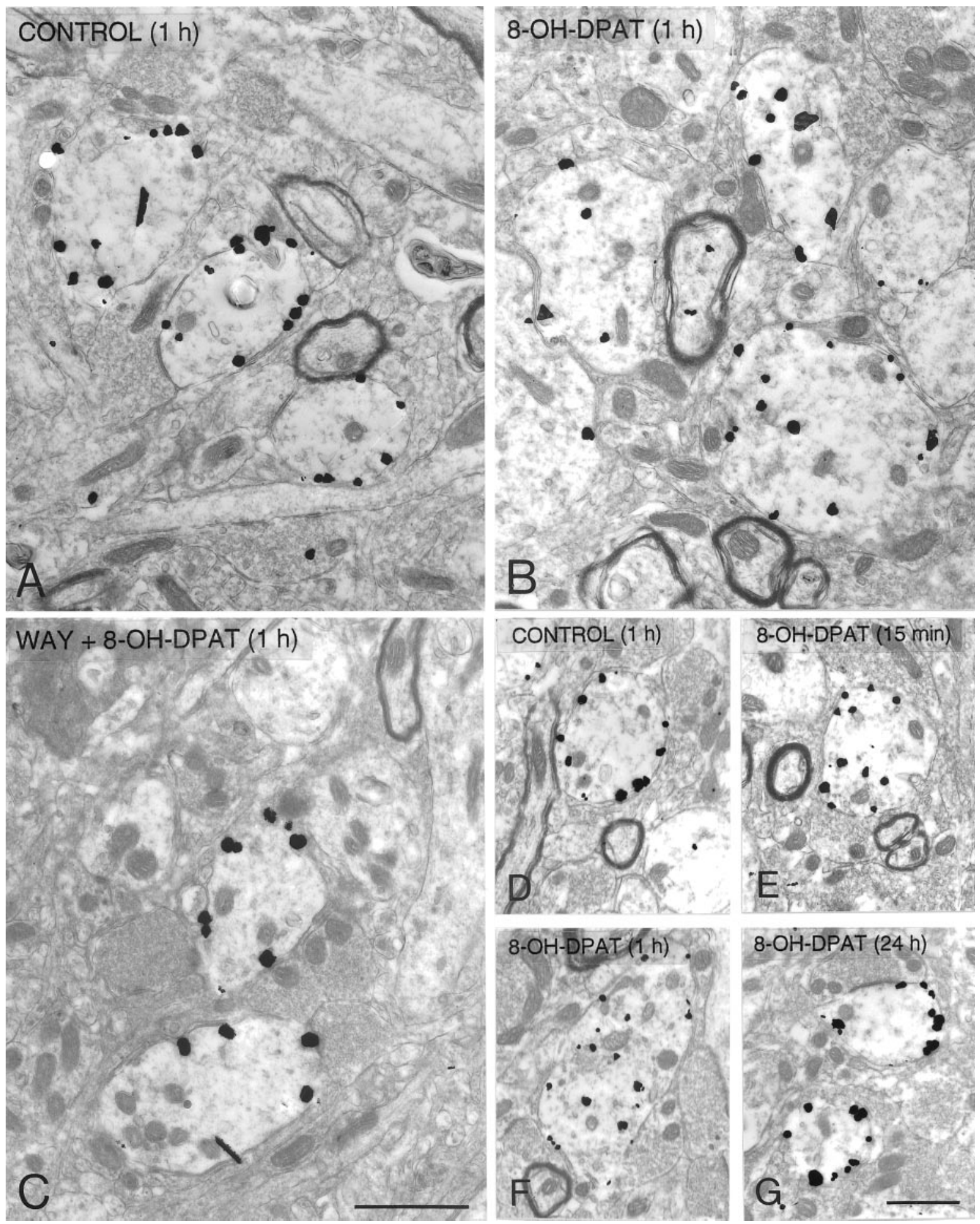

Figure 3. Silver-intensified immunogold labeling of 5-HT $\mathrm{HA}_{1 \mathrm{~A}}$ receptors in dendrites from the NRD of saline controls $(A, D)$, rats treated 1 hr before fixation with 8-OH-DPAT $(B)$ or WAY-100635 followed by 8-OH-DPAT $(C)$, and rats treated with 8-OH-DPAT, $15 \mathrm{~min}(E), 1 \mathrm{hr}(F)$, or $24 \mathrm{hr}(G)$ before fixation. Note the predilection of the immunogold particles for the plasma membrane in the controls and the rats treated with WAY 100635 before 8-OH-DPAT, or injected with 8-OH-DPAT $24 \mathrm{hr}$ before, and for the cytoplasm in the rats injected $15 \mathrm{~min}$ or $1 \mathrm{hr}$ before fixation. Scale bar, $1 \mu \mathrm{m}$. Magnification: $A-C, 18,000 \times ; D-G, 11,000 \times$.

$3 A, D)$. As shown in Table $1,67 \%$ of the silver-intensified immunogold particles in somata and $86 \%$ in dendrites were associated with the plasma membrane, whereas this compartment represented only 3 and $7 \%$, respectively, of the total cellular surfaces that were examined. The ratios of plasma membrane to cytoplas- mic labeling were thus estimated at $66: 1$ and $82: 1$ in the somata and dendrites, respectively.

One hour after a single injection of 8-OH-DPAT, the number of immunogold particles associated with the plasma membrane of NRD somata and dendrites was markedly decreased as compared 


\section{RAPHE DORSALIS}

Somata

Figure 4. Comparison of the density (number of silver-intensified immunogold particles per square micrometer) of $5-\mathrm{HT}_{1 \mathrm{~A}}$ autoreceptors in the plasma membrane compartment of NRD somata and dendrites from rats injected with saline $(n=8), 8-\mathrm{OH}-$ DPAT $(n=6)$, WAY 100635 followed by 8-OH-DPAT $(n=5)$, or WAY 100635 alone $(n=3), 1 \mathrm{hr}$ before fixation. Data normalized to control $(100 \%)$. See Materials and Methods for details of analysis. 8-OH-DPAT significantly lower than control $(p<0.001)$.
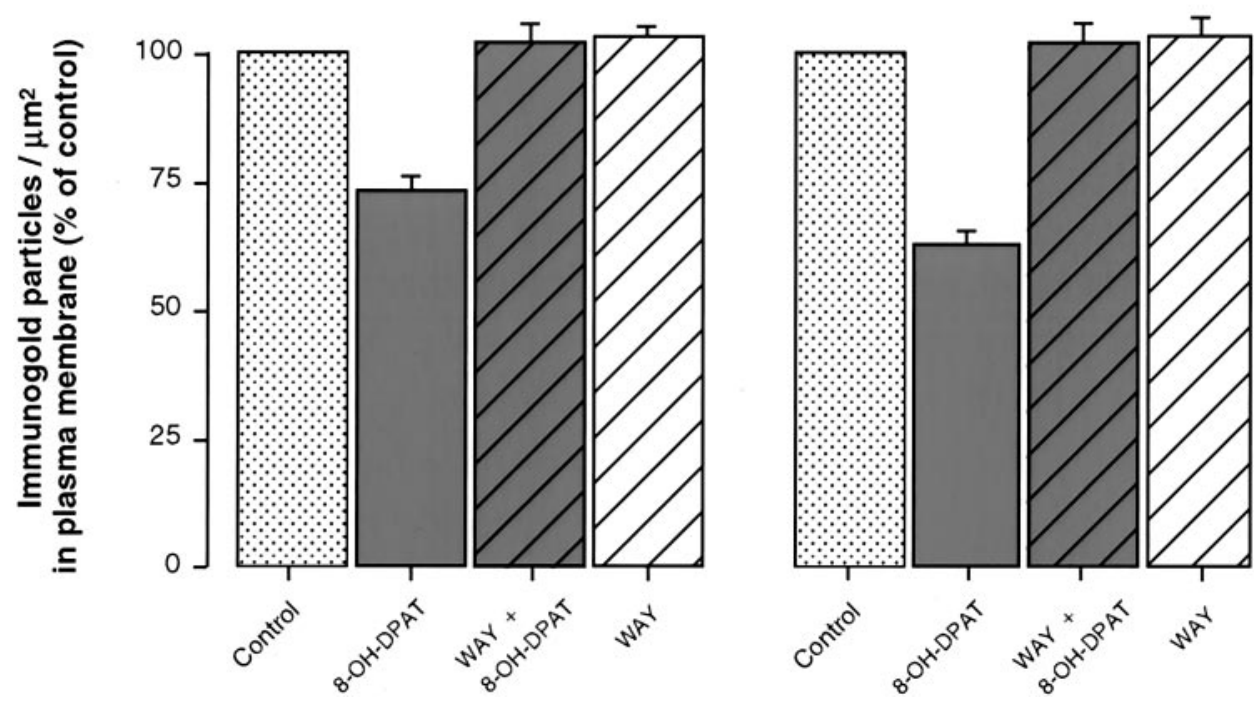

with controls (Figs. $2 B, 3 B, F$ ). The proportion of membraneassociated gold particles then fell from 67 to $44 \%$ in somata and from 86 to $53 \%$ in dendrites (Table 1), and the corresponding ratios of plasma membrane to cytoplasmic labeling from $66: 1$ to 25:1, and from 82:1 to 15:1. As shown in Figure 4, when normalized to a control density of labeling (number of particles per unit of surface) of $100 \%$, this effect on the distribution of the receptor corresponded to 28 and $37 \%$ decreases for the plasma membrane compartment of somata and dendrites, respectively (Fig. 4), and increases of 58 and $203 \%$ for their cytoplasmic compartment (data not shown).

An additional difference from controls in the 8-OH-DPATtreated rats was the greater frequency of immunogold particles associated with endosome-like profiles in the cytoplasmic compartment of NRD perikarya (Fig. 2B). These represented $36 \%$ of all cytoplasmic particles in the treated rats versus $13 \%$ in the controls $(p<0.01)$.

Pretreatment with the $5-\mathrm{HT}_{1 \mathrm{~A}}$ receptor antagonist WAY 100635 completely prevented the 8-OH-DPAT-induced effect (Figs. 3C, 4). The proportion of plasma membrane-associated gold particles in NRD somata and dendrites was then the same as in controls, $1 \mathrm{hr}$ after 8-OH-DPAT injection (Table 1). Treatment with WAY 100635 alone had no apparent effect on the distribution of $5-\mathrm{HT}_{1 \mathrm{~A}}$ receptors (Fig. 4, Table 1).

The decrease in number of plasma membrane-associated gold particles was already detectable $15 \mathrm{~min}$ after 8-OH-DPAT injection (Figs. $3 E, 5$ ), at which time it corresponded to $64 \%$ of the control value in NRD dendrites and was therefore comparable in magnitude to that after $1 \mathrm{hr}$ (Figs. 3F, 5). The concomitant increase in cytoplasmic labeling was $275 \%$ of the control value. Twenty-four hours after 8-OH-DPAT injection, the $5-\mathrm{HT}_{1 \mathrm{~A}}$ labeling was indistinguishable from that seen in control rats (Figs. $3 G, 5)$.

\section{Hippocampus (CA3)}

As previously described in normal rats (Riad et al., 2000), the immunogold labeling of 5- $\mathrm{HT}_{1 \mathrm{~A}}$ receptors in the hippocampus of saline-injected controls also showed predilection for the plasma membrane versus cytoplasm of CA3 pyramidal cell dendrites (Fig. 6A). Indeed, the ratio of density between the two compartments was 50:1. In contrast to the marked redistribution of $5-\mathrm{HT}_{1 \mathrm{~A}}$ receptors observed in NRD somata and dendrites, there were no changes from controls in CA3 hippocampal dendrites 1 hr after 8-OH-DPAT injection (Figs. 6B, 7).

\section{RAPHE DORSALIS}
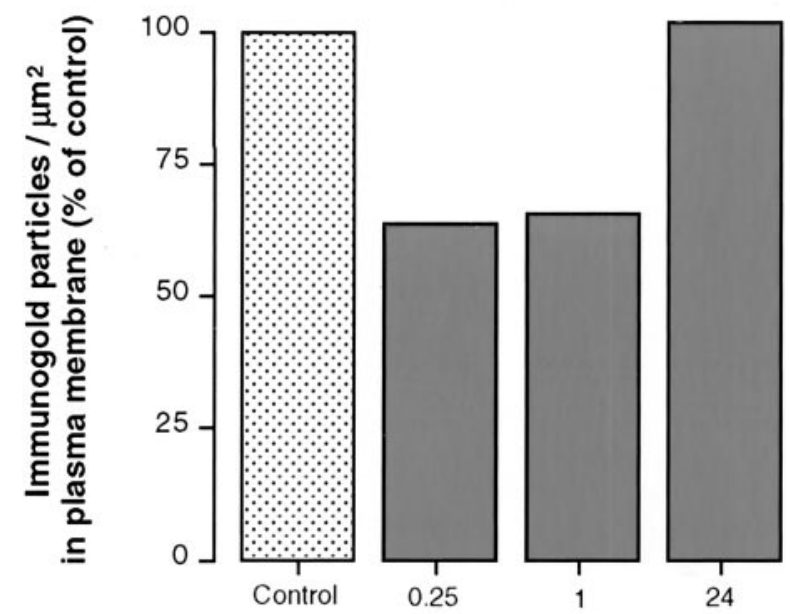

Time after 8-OH-DPAT (h)

Figure 5. Density of 5- $\mathrm{HT}_{1 \mathrm{~A}}$ autoreceptor immunogold labeling in the plasma membrane compartment of NRD dendrites from a saline-injected control and rats injected with 8-OH-DPAT, $15 \mathrm{~min}(n=1), 1 \mathrm{hr}(n=1)$, or $24 \mathrm{hr}(n=1)$ before fixation. The material from these four rats was simultaneously processed for immunocytochemistry and analyzed as in Figure 4. 

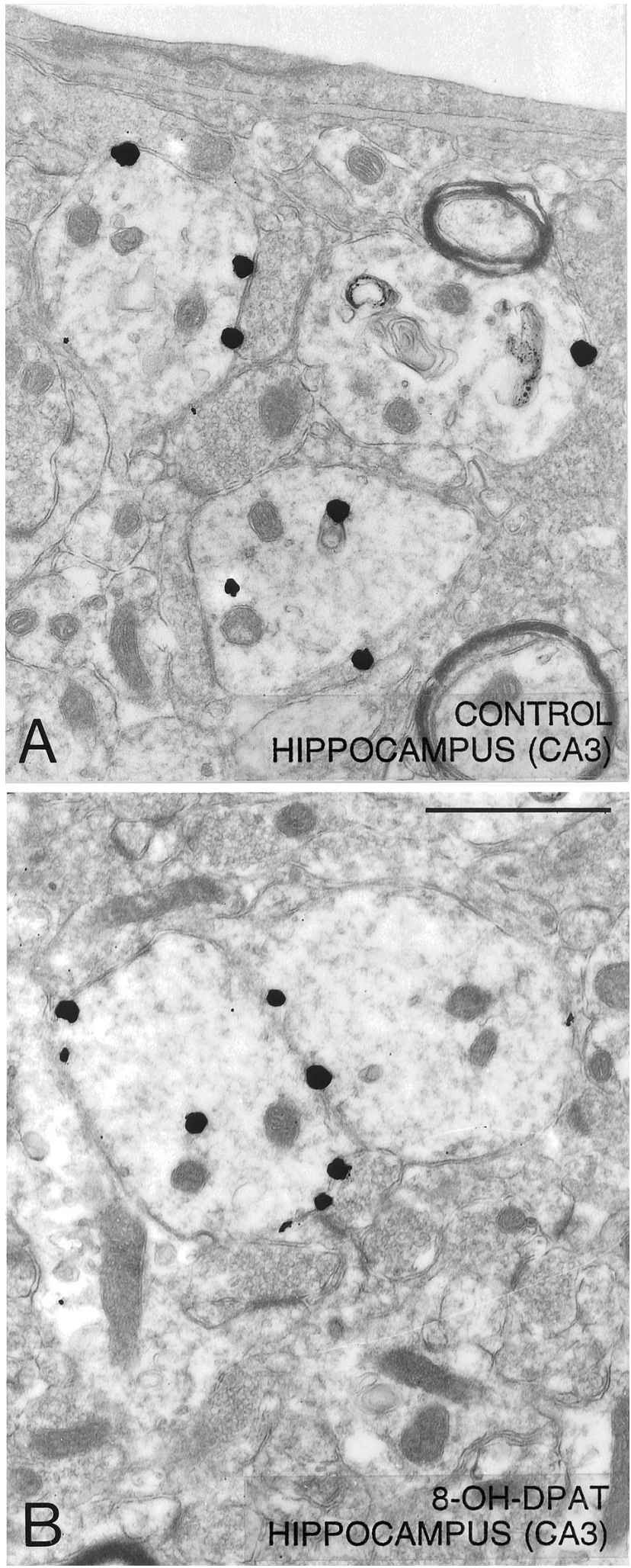

Figure 6. Low-power electron micrographs illustrating the distribution of 5-HT $\mathrm{HT}_{1 \mathrm{~A}}$ immunoreactivity (immunogold-labeled) in dendrites of the hippocampus (CA3) from a saline-control $(A)$ and a rat treated with 8-OH-DPAT, $1 \mathrm{hr}$ before fixation $(B)$. In contrast with the situation in the NRD, the majority of silver-intensified immunogold particles are associated with the plasma membrane as opposed to the cytoplasm of labeled dendrites in both the saline control and the 8-OH-DPAT-treated rat. Magnification, 24,000×. Scale bar, $1 \mu \mathrm{m}$.

\section{HIPPOCAMPUS}

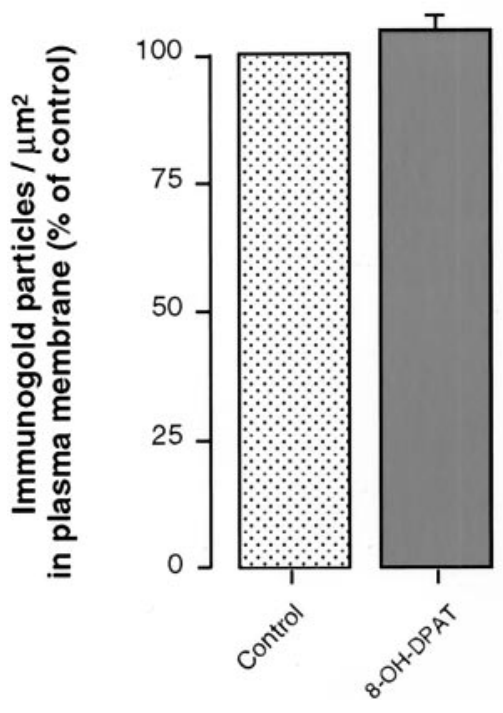

Figure 7. Density of 5- $\mathrm{HT}_{1 \mathrm{~A}}$ heteroreceptor immunogold labeling in the plasma membrane compartment of hippocampal (CA3) dendrites from saline-injected controls $(n=3)$ and rats injected with 8-OH-DPAT $(n=$ $3), 1 \mathrm{hr}$ before fixation. Material analyzed as in preceding figures.

\section{DISCUSSION}

The present quantitative electron microscopic immunogold study is the first to demonstrate an agonist-induced internalization of $5-\mathrm{HT}_{1 \mathrm{~A}}$ receptors in vivo. In control rats, the strong enrichment of these receptors in the plasma membrane versus the cytoplasm of NRD cell bodies and dendrites (autoreceptors), as well as dendrites of CA3 pyramidal neurons (heteroreceptors), was in keeping with earlier findings (Riad et al., 2000). The lowering of the ratios of plasma membrane to cytoplasmic labeling from $66: 1$ to $25: 1$ and from $82: 1$ to $15: 1$ in NRD somata and dendrites, respectively, after a single intravenous injection of the potent 5-HT ${ }_{1 \mathrm{~A}}$ agonist 8-OH-DPAT (Gozlan et al., 1983), indicated internalization of a large proportion of these membraneassociated autoreceptors. This appeared to be a maximal effect, because, in a preliminary experiment, a decrease of comparable magnitude had been measured after intraperitoneal administration of a 10-fold higher dose of 8-OH-DPAT ( $5 \mathrm{mg} / \mathrm{kg}$; Riad et al., 1999). Admittedly, if all grains here assigned to the plasma membrane compartment did represent membrane-bound receptors, the true concentrations within the much thinner membrane itself, and hence the membrane to cytoplasm ratios, were grossly underestimated. Yet, they provided a useful and reliable index to measure drug effects.

The internalization after 8-OH-DPAT could indeed be attributed to the activation of $5-\mathrm{HT}_{1 \mathrm{~A}}$ autoreceptors, because it was completely abolished by pretreatment with the selective $5-\mathrm{HT}_{1 \mathrm{~A}}$ antagonist WAY 100635, which is known to compete with the agonist for the same binding site on the receptor (Gozlan et al., 1995). The fact that WAY 100635 by itself was without any apparent effect seemed to exclude a tonic influence of endogenous extracellular 5-HT on the subcellular distribution of 5- $\mathrm{HT}_{1 \mathrm{~A}}$ autoreceptors. Such a lack of effect of endogenous 5-HT is in turn consistent with electrophysiological observations showing that WAY 100635 efficiently blocks the inhibitory effects of 5-HT agonists, but does not affect, on its own, 5-HT neuron firing 
(Mundey et al., 1994; Corradetti et al., 1996; Martin et al., 1999). Furthermore, neuroendocrine studies have indicated that WAY 100635 inhibits 8-OH-DPAT-stimulated oxytocin, ACTH, and corticosterone secretion, without altering the basal levels of these hormones (Vicentic et al., 1998).

An internalization of the same magnitude as after $1 \mathrm{hr}$ was already detectable as soon as 15 min after 8-OH-DPAT injection, and presumably lasted for several hours, with a return to control values within $24 \mathrm{hr}$. This suggested a recycling of a majority of $5-\mathrm{HT}_{1 \mathrm{~A}}$ autoreceptors, although degradation and neosynthesis could not be excluded in this time frame. The relatively high proportion of immunoreactive $5-\mathrm{HT}_{1 \mathrm{~A}}$ receptors associated with endosome-like vesicles in both NRD cell bodies and dendrites after 8-OH-DPAT injection suggested that such a translocation from the plasma membrane to the cytoplasm occurred through endocytosis. Indeed, the implication of endocytotic mechanisms has already been documented for the in vivo translocation of other G-protein-coupled receptors, notably: dopamine D1 (Dumartin et al., 1998), muscarinic m2 and m4 (Bernard et al., 1998, 1999), $\mu$-opioid (Sternini et al., 1996), neurotensin (Faure et al., 1995), and substance P (Mantyh et al., 1995) receptors. In the case of 5-HT receptors, studies of permanently transfected GF-62 cells have shown that the endosome pathway also plays a key role in the internalization of $5-\mathrm{HT}_{2 \mathrm{~A}}$ receptors triggered by stimulation with the 5- $\mathrm{HT}_{2 \mathrm{~A}}$ agonist quipazine (Berry et al., 1996).

8-OH-DPAT-induced internalization of 5- $\mathrm{HT}_{1 \mathrm{~A}}$ autoreceptors apparently took place in all immunolabeled somata and dendrites of the NRD, revealing their functionality in 5-HT neurons. As previously described (Riad et al., 2000), these $5-\mathrm{HT}_{1 \mathrm{~A}}$ receptors are mostly located outside synapses in the plasma membrane of somata and dendrites in NRD or hippocampus. It is likely that such extrasynaptic or nonsynaptic receptors are reached by 5 -HT diffusing from specific release sites.

The present quantitative results also substantiated the markedly different responsiveness to agonist of 5- $\mathrm{HT}_{1 \mathrm{~A}}$ autoreceptors versus heteroreceptors: internalization occurred in the NRD but not in the hippocampus. Binding studies had already shown that acute treatment with 8 -OH-DPAT $(1 \mathrm{mg} / \mathrm{kg}$, s.c.) significantly decreased the number $\left(B_{\max }\right)$ of $5-\mathrm{HT}_{1 \mathrm{~A}}$ binding sites in rat NRD, but not hippocampus or frontal cortex, without any change in the binding affinity $\left(K_{\mathrm{d}}\right)$ in either region (Beer et al., 1990). Similarly, the density of $5-\mathrm{HT}_{1 \mathrm{~A}}$ autoreceptors labeled with $\left[{ }^{3} \mathrm{H}\right] 8-\mathrm{OH}-\mathrm{DPAT}$ was found to be reduced in NRD and not hippocampus after treatment for $21 \mathrm{~d}$ with the $5-\mathrm{HT}_{1 \mathrm{~A}}$ receptor agonists gepirone (Welner et al., 1989) and ipsapirone (Fanelli and McMonagle-Strucko, 1992) (but see Larsson et al., 1990; Schechter et al., 1990; Wieland et al., 1993). Behavioral studies have also led to the conclusion that acute or subchronic treatment with 8-OH-DPAT decreased the so-called "presynaptic" (autoreceptor) but not "postsynaptic" (heteroreceptor) 5-HT $\mathrm{HA}_{1 \mathrm{~A}}$-mediated responsiveness (Kennett et al., 1987b; O'Connell and Curzon, 1996). Last, a number of electrophysiological studies have indicated that chronic administration of $5-\mathrm{HT}_{1 \mathrm{~A}}$ receptor agonists results in desensitization of $5-\mathrm{HT}_{1 \mathrm{~A}}$ autoreceptors in the $\mathrm{NRD}$, but not of postsynaptic $5-\mathrm{HT}_{1 \mathrm{~A}}$ receptors in the hippocampus (Blier and de Montigny, 1987, 1990; Schechter et al., 1990; Godbout et al., 1991; Dong et al., 1997; Sim-Selley et al., 2000; Le Poul et al., 2000).

Unlike 8-OH-DPAT, which generally acts as a full $5-\mathrm{HT}_{1 \mathrm{~A}}$ receptor agonist (Hoyer et al., 1994), most of the drugs that completely inhibit 5-HT neuron firing activity produce only partial agonistic effects at postsynaptic $5-\mathrm{HT}_{1 \mathrm{~A}}$ sites in hippocampus
(Andrade and Nicoll, 1987; Blier and de Montigny, 1992; Hadrava et al., 1995; Dong et al., 1997). Conversely, several compounds previously thought to act as $5-\mathrm{HT}_{1 \mathrm{~A}}$ receptor antagonists at postsynaptic sites have been shown to produce submaximal agonistic effects at presynaptic sites inhibiting 5-HT neuron firing (Millan et al., 1994; Newman-Tancredi et al., 1997). Yet, there is no definitive biomolecular evidence that these two populations of receptors are distinct entities. It has been suggested that coupling of the same receptor to different G-proteins might explain such regional differences in pharmacology (Kenakin, 1995). The fact that the administration of cholera toxin does not alter responsiveness of NRD 5-HT neurons to the microiontophoretic application of 5-HT or 8-OH-DPAT, but reduces that of CA3 neurons by $90 \%$ (Blier et al., 1993), provides some support for the hypothesis that differences in G-protein coupling might concern 5-HT receptors in these two regions.

Our data suggest that, after acute treatment with 8-OH-DPAT, the subsequent decrease in $5-\mathrm{HT}_{1 \mathrm{~A}}$ autoreceptor responsiveness might be caused by a reduction of their density in the plasma membrane as a consequence of receptor internalization. Desensitization of $5-\mathrm{HT}_{1 \mathrm{~A}}$ autoreceptors associated with a decrease in their density has recently been reported by Li et al. (1999, 2000) and Fabre et al. (2000) in 5-HT transporter knock-out mice displaying increased extracellular levels of 5-HT throughout brain. Interestingly, the decrease in $5-\mathrm{HT}_{1 \mathrm{~A}}$ autoreceptor density associated with the desensitization in these mutants was of the same magnitude (30-50\%) as the proportion of membrane bound $5-\mathrm{HT}_{1 \mathrm{~A}}$ autoreceptors here shown to be internalized after a single dose of agonist.

It has been repeatedly postulated that desensitization of NRD $5-\mathrm{HT}_{1 \mathrm{~A}}$ autoreceptors is a determinant of the therapeutic efficacy of antidepressant treatments aimed at increasing 5-HT neurotransmission in selected areas of the brain (Blier and de Montigny, 1994). After chronic treatment with monoamine oxidase inhibitors or selective serotonin reuptake inhibitors, desensitization of NRD 5-HT $\mathrm{HA}_{1 \mathrm{~A}}$ autoreceptors has been observed in the absence of any changes in $5-\mathrm{HT}_{1 \mathrm{~A}}$ receptor-mediated effector responses in hippocampus (Blier et al., 1988; Jolas et al., 1994; Le Poul et al., 2000). Similarly, electrophysiological studies in various animal models of stress have shown a desensitization of NRD 5-HT $\mathrm{HA}_{1 \mathrm{~A}}$ autoreceptors, but not hippocampal 5-HT $\mathrm{HA}_{1 \mathrm{~A}}$ heteroreceptors (Laaris et al., 1999; Lanfumey et al., 1999). Conversely, it may be expected that the density of membrane-bound NRD $5-\mathrm{HT}_{1 \mathrm{~A}}$ autoreceptors will rise under conditions of chronic lowering of extracellular 5-HT levels in brain. This would be consistent with recent observations of Stockmeier et al. (1998), who reported significant increases in the binding of $\left[{ }^{3} \mathrm{H}\right] 8-\mathrm{OH}-\mathrm{DPAT}$ to $5-\mathrm{HT}_{1 \mathrm{~A}}$ receptors in the $\mathrm{NRD}$ of suicide victims with major depression.

The main conclusion from the present study is that internalization may account for the desensitization of $5-\mathrm{HT}_{1 \mathrm{~A}}$ autoreceptors that follows their acute activation, whereas $5-\mathrm{HT}_{1 \mathrm{~A}}$ heteroreceptors do not internalize under the same conditions. Internalization of the 5- $\mathrm{HT}_{1 \mathrm{~A}}$ autoreceptors should prevent autoinhibition of the firing of NRD neurons by 5-HT, and hence increase 5-HT transmission in target zones. It could thus play a key role in the therapeutic efficacy of antidepressants.

\section{REFERENCES}

Andrade R, Nicoll RA (1987) Novel anxiolytics discriminate between postsynaptic serotonin receptors mediating different physiological responses on single neurons of the rat hippocampus. Naunyn Schmiedebergs Arch Pharmacol 336:5-10. 
Artigas F, Romero L, de Montigny C, Blier P (1996) Acceleration of the effect of selected antidepressant drugs in major depression by $5-\mathrm{HT}_{1 \mathrm{~A}}$ antagonists. Trends Neurosci 19:378-383.

Barnes NM, Sharp T (1999) A review of central 5-HT receptors and their function. Neuropharmacology 38:1083-1152.

Beer M, Kennett GA, Curzon G (1990) A single dose of 8-OH-DPAT reduces raphe binding of $\left[{ }^{3} \mathrm{H}\right] 8-\mathrm{OH}-\mathrm{DPAT}$ and increases the effect of raphe stimulation on 5-HT metabolism. Eur J Pharmacol 178:179-187.

Bernard V, Laribi O, Levey AI, Bloch B (1998) Subcellular redistribution of $\mathrm{m} 2$ muscarinic acetylcholine receptors in striatal interneurons in vivo after acute cholinergic stimulation. J Neurosci 18:10207-10218.

Bernard V, Levey AI, Bloch B (1999) Regulation of the subcellular distribution of $\mathrm{m} 4$ muscarinic acetylcholine receptors in striatal neurons in vivo by the cholinergic environment: evidence for regulation of cell surface receptors by endogenous and exogenous stimulation. J Neurosci 19:10237-10249.

Berry SA, Shah MC, Khan N, Roth BL (1996) Rapid agonist-induced internalization of the 5-hydroxytryptamine $2 \mathrm{~A}$ receptor occurs via the endosome pathway in vitro. Mol Pharmacol 50:306-313.

Bhatnagar A, Willins DL, Gray JA, Woods J, Benovic JL, Roth BL (2001) The dynamin-dependent, arrestin-independent internalization of 5-hydroxytryptamine $2 \mathrm{~A}\left(5-\mathrm{HT}_{2 \mathrm{~A}}\right)$ serotonin receptors reveals differential sorting of arrestins and $5-\mathrm{HT}_{2 \mathrm{~A}}$ receptors during endocytosis. J Biol Chem 276:8269-8277.

Blier P, de Montigny C (1987) Modification of 5-HT neuron properties by sustained administration of the $5-\mathrm{HT}_{1 \mathrm{~A}}$ agonist gepirone: electrophysiological studies in the rat brain. Synapse 1:470-480.

Blier P, de Montigny C (1990) Electrophysiological investigation of the adaptive response of the 5-HT system to the administration of $5-\mathrm{HT}_{1 \mathrm{~A}}$ receptor agonists. J Cardiovasc Pharmacol 15:S42-S48.

Blier P, de Montigny C (1992) Electrophysiological studies on the heterogeneity of 5-HT $\mathrm{HT}_{1 \mathrm{~A}}$ receptors: psychopharmacological implications. Clin Neuropharmacol 15:137A-138A.

Blier P, de Montigny C (1994) Current advances and trends in the treatment of depression. Trends Pharmacol Sci 15:220-226.

Blier P, de Montigny C (1999) Serotonin and drug-induced therapeutic responses in major depression, obsessive-compulsive and panic disorders. Neuropsychopharmacology [Suppl] 2:91-98.

Blier P, Chaput Y, de Montigny C (1988) Long-term 5-HT reuptake blockade, but not monoamine oxidase inhibition, decreases the function of terminal 5-HT autoreceptors: an electrophysiological study in the rat brain. Naunyn Schmiedebergs Arch Pharmacol 337:246-254.

Blier P, Lista A, de Montigny C (1993) Differential properties of preand postsynaptic 5-hydroxytryptamine1A receptors in the dorsal raphe and hippocampus. II. Effect of pertussis and cholera toxins. J Pharmacol Exp Ther 265:16-23.

Bonvento G, Scatton B, Claustre Y, Rouquier L (1992) Effect of local injection of 8-OH-DPAT into the dorsal or median raphe nuclei on extracellular levels of serotonin in serotonergic projection areas in the rat brain. Neurosci Lett 137:101-104.

Boudin H, Sarret P, Mazella J, Schonbrunn A, Beaudet A (2000) Somatostatin-induced regulation of $\mathrm{SST}(2 \mathrm{~A})$ receptor expression and cell surface availability in central neurons: role of receptor internalization. J Neurosci 20:5932-5939.

Carli M, Samanin R (1988) Potential anxiolytic properties of 8-hydroxy2-(di- $N$-propylamino)tetralin, a selective serotonin1A receptor agonist. Psychopharmacology 94:84-91.

Corradetti R, Le Poul E, Laaris N, Hamon M, Lanfumey L (1996) Electrophysiological effects of $N$-(2-(4-(2-methoxyphenyl)-1-piperazinyl)ethyl)- $N$-(2-pyridinyl) cyclohexane carbo-xamide (WAY 100635) on dorsal raphe serotonergic neurons and CA1 hippocampal pyramidal cells in vitro. J Pharmacol Exp Ther 278:679-688.

Della Rocca GJ, Mukhin YV, Garnovskaya MN, Daaka Y, Clark GJ, Luttrell LM, Lefkowitz RJ, Raymond JR (1999) Serotonin 5-HT receptor-mediated Erk activation requires calcium/calmodulindependent receptor endocytosis. J Biol Chem 274:4749-4753.

Dong J, de Montigny C, Blier P (1997) Effect of acute and repeated versus sustained administration of the $5-\mathrm{HT}_{1 \mathrm{~A}}$ receptor agonist ipsapirone: electrophysiological studies in the rat hippocampus and dorsal raphe. Naunyn Schmiedebergs Arch Pharmacol 356:303-311.

Dumartin B, Caille I, Gonon F, Bloch B (1998) Internalization of D1 dopamine receptor in striatal neurons in vivo as evidence of activation by dopamine agonists. J Neurosci 18:1650-1661.

El Mestikawy S, Riad M, Laporte AM, Vergé D, Daval G, Gozlan H, Hamon M (1990) Production of specific anti-5-HT A $_{1}$ receptor antibodies in rabbits injected with a synthetic peptide. Neurosci Lett 118:189-192.

Fabre V, Beaufour C, Evrard A, Rioux A, Hanoun N, Lesch KP, Murphy DL, Lanfumey L, Hamon M, Martres MP (2000) Altered expression and functions of serotonin $5-\mathrm{HT}_{1 \mathrm{~A}}$ and $5-\mathrm{HT} 1 \mathrm{~B}$ receptors in knock-out mice lacking the 5-HT transporter. Eur J Neurosci 12:2299-2310.

Fanelli RJ, McMonagle-Strucko K (1992) Alteration of 5-HT A $_{\text {A }}$ receptor binding sites following chronic treatment with ipsapirone measured by quantitative autoradiography. Synapse 12:75-81.

Faure MP, Alonso A, Nouel D, Gaudriault G, Dennis M, Vincent JP,
Beaudet A (1995) Somatodendritic internalization and perinuclear targeting of neurotensin in the mammalian brain. $\mathrm{J}$ Neurosci 15:4140-4147.

Godbout R, Chaput Y, Blier P, de Montigny C (1991) Tandospirone and its metabolite, 1-(2-pyrimidinyl)-piperazine. I. Effects of acute and long-term administration of tandospirone on serotonin neurotransmission. Neuropharmacology 30:679-690.

Gozlan H, El Mestikawy S, Pichat L, Glowinski J, Hamon M (1983) Identification of presynaptic serotonin autoreceptors using a new ligand: ${ }^{3}$ H-PAT. Nature 305:140-142.

Gozlan H, Thibault S, Laporte AM, Lima L, Hamon M (1995) The selective $5-\mathrm{HT}_{1 \mathrm{~A}}$ antagonist radioligand $\left[{ }^{3} \mathrm{H}\right] \mathrm{WAY} 100635$ labels both $\mathrm{G}$-protein-coupled and free $5-\mathrm{HT}_{1 \mathrm{~A}}$ receptors in rat brain membranes. Eur J Pharmacol 288:173-186.

Hadrava V, Blier P, Dennis T, Ortemann C, de Montigny C (1995) Characterization of 5-hydroxytryptamine1A properties of flesinoxan: in vivo electrophysiology and hypothermia study. Neuropharmacology 34:1311-1326.

Hamon M, Fattaccini CM, Adrien J, Gallissot MC, Martin P, Gozlan H (1988) Alterations of central serotonin and dopamine turnover in rats treated with ipsapirone and other 5-hydroxytryptamine1A agonists with potential anxiolytic properties. J Pharmacol Exp Ther 246:745-752.

Hillion J, Catelon J, Riad M, Hamon M, De Vitry F (1994) Neuronal localization of $5-\mathrm{HT}_{1 \mathrm{~A}}$ receptor $\mathrm{mRNA}$ and protein in rat embryonic brain stem cultures. Dev Brain Res 79:195-202.

Hjorth S, Magnusson T (1988) The 5- $\mathrm{HT}_{1 \mathrm{~A}}$ receptor agonist, 8-OHDPAT, preferentially activates cell body 5-HT autoreceptors in rat brain in vivo. Naunyn Schmiedebergs Arch Pharmacol 338:463-471.

Hoyer D, Clarke DE, Fozard JR, Hartig PR, Martin GR, Mylecharane EJ, Saxena PR, Humphrey PP (1994) International Union of Pharmacology classification of receptors for 5-hydroxytryptamine (serotonin). Pharmacol Rev 46:157-203.

Invernizzi R, Carli M, Di Clemente A, Samanin R (1991) Administration of 8-hydroxy-2-(di- $N$-propylamino)tetralin in raphe nuclei dorsalis and medianus reduces serotonin synthesis in the rat brain: differences in potency and regional sensitivity. J Neurochem 56:243-247.

Jolas T, Haj-Dahmane S, Kidd EJ, Langlois X, Lanfumey L, Fattaccini CM, Vantalon V, Laporte AM, Adrien J, Gozlan H, Hamon M (1994) Central pre- and postsynaptic $5-\mathrm{HT}_{1 \mathrm{~A}}$ receptors in rats treated chronically with a novel antidepressant, cericlamine. J Pharmacol Exp Ther 268:1432-1443.

Kenakin T (1995) Agonist-receptor efficacy and receptor promiscuity. Trends Pharmacol Sci 16:188-192.

Kennett GA, Dourish CT, Curzon G (1987a) Antidepressant-like action of 5-HT $\mathrm{HT}_{1 \mathrm{~A}}$ agonists and conventional antidepressants in an animal model of depression. Eur J Pharmacol 134:265-274

Kennett GA, Marcou M, Dourish CT, Curzon G (1987b) Single administration of $5-\mathrm{HT}_{1 \mathrm{~A}}$ agonists decreases $5-\mathrm{HT}_{1 \mathrm{~A}}$ presynaptic, but not postsynaptic receptor-mediated responses: relationship to antidepressant-like action. Eur J Pharmacol 138:53-60.

Laaris N, Le Poul E, Laporte AM, Hamon M, Lanfumey L (1999) Differential effects of stress on presynaptic and postsynaptic 5-hydroxytryptamine-1A receptors in the rat brain: an in vitro electrophysiological study. Neuroscience 91:947-958.

Lanfumey L, Pardon MC, Laaris N, Joubert C, Hanoun N, Hamon M, Cohen-Salmon C (1999) $5-\mathrm{HT}_{1 \mathrm{~A}}$ autoreceptor desensitization by chronic ultramild stress in mice. NeuroReport 10:3369-3374.

Larsson LG, Renyi L, Ross SB, Svensson B, Angeby-Moller K (1990) Different effects on the responses of functional pre- and postsynaptic $5-\mathrm{HT}_{1 \mathrm{~A}}$ receptors by repeated treatment of rats with the $5-\mathrm{HT}_{1 \mathrm{~A}}$ receptor agonist 8-OH-DPAT. Neuropharmacology 29:86-91.

Le Poul E, Boni C, Hanoun N, Laporte AM, Laaris N, Chauveau J, Hamon M, Lanfumey L (2000) Differential adaptation of brain $5-\mathrm{HT}_{1 \mathrm{~A}}$ and $5-\mathrm{HT}_{1 \mathrm{~B}}$ receptors and 5 -HT transporter in rats treated chronically with fluoxetine. Neuropharmacology 39:110-122.

Li Q, Wichems C, Heils A, Van de Kar LD, Lesch KP, Murphy DL (1999) Reduction of 5-hydroxytryptamine (5-HT)(1A)-mediated temperature and neuroendocrine responses and 5-HT(1A) binding sites in 5-HT transporter knockout mice. J Pharmacol Exp Ther 291:999-1007.

Li Q, Wichems C, Heils A, Lesch KP, Murphy DL (2000) Reduction in the density and expression, but not G-protein coupling, of serotonin receptors $\left(5-\mathrm{HT}_{1 \mathrm{~A}}\right)$ in 5-HT transporter knock-out mice: gender and brain region differences. J Neurosci 20:7888-7895.

Mantyh PW, Allen CJ, Ghilardi JR, Rogers SD, Mantyh CR, Liu H Basbaum AI, Vigna SR, Maggio JE (1995) Rapid endocytosis of a G protein-coupled receptor: substance $\mathrm{P}$ evoked internalization of its receptor in the rat striatum in vivo. Proc Natl Acad Sci USA 92:2622-2626.

Martin LP, Jackson DM, Wallsten C, Waszczak BL (1999) Electrophysiological comparison of 5-hydroxytryptamine1A receptor antagonists on dorsal raphe cell firing. J Pharmacol Exp Ther 288:820-826.

Martin P, Beninger RJ, Hamon M, Puech AJ (1990) Antidepressant-like action of 8-OH-DPAT, a 5-HT $\mathrm{HT}_{1 \mathrm{~A}}$ agonist, in the learned helplessness 
paradigm: evidence for a postsynaptic mechanism. Behav Brain Res 38:135-144.

Millan MJ, Canton H, Gobert A, Lejeune F, Rivet JM, Bervoets K, Brocco M, Widdowson P, Mennini T, Audinot V, Honore P, Renuard A, Le Marouille-Girardon S, Verriele L, Gressier H, Peglion J-L (1994) Novel benzodioxopiperazines acting as antagonists at postsynaptic $5-\mathrm{HT}_{1 \mathrm{~A}}$ receptors and as agonists at 5- $\mathrm{HT}_{1 \mathrm{~A}}$ autoreceptors: a comparative pharmacological characterization with proposed $5-\mathrm{HT}_{1 \mathrm{~A}}$ antagonists. J Pharmacol Exp Ther 268:337-352.

Mundey MK, Fletcher A, Marsden CA (1994) Effect of the putative $5-\mathrm{HT}_{1 \mathrm{~A}}$ antagonist WAY-100635 on 5-HT neuronal firing in the guinea-pig dorsal raphe nucleus. Neuropharmacology 3:61-66.

Murphy DL (1990) Neuropsychiatric disorders and the multiple human brain serotonin receptor subtypes and subsystems. Neuropsychopharmacology 3:457-471.

Nebigil CG, Garnovskaya MN, Casanas SJ, Mulheron JG, Parker EM, Gettys TW, Raymond JR (1995) Agonist-induced desensitization and phosphorylation of human $5-\mathrm{HT}_{1 \mathrm{~A}}$ receptor expressed in $\mathrm{Sf} 9$ insect cells. Biochemistry 34:11954-11962.

Newman-Tancredi A, Conte C, Chaput C, Verriele L, Millan MJ (1997) Agonist and inverse agonist efficacy at human recombinant serotonin $5-\mathrm{HT}_{1 \mathrm{~A}}$ receptors as a function of receptor: G-protein stoichiometry. Neuropharmacology 36:451-459.

O'Connell MT, Curzon G (1996) A comparison of the effects of 8-OHDPAT pretreatment on different behavioural responses to $8-\mathrm{OH}-$ DPAT. Eur J Pharmacol 312:137-143.

Paxinos G, Watson C (1986) The rat brain in stereotaxic coordinates (Ed 2). Sydney: Academic.

Picazo O, Lopez-Rubalcava C, Fernandez-Guasti A (1995) Anxiolytic effect of the $5-\mathrm{HT}_{1 \mathrm{~A}}$ compounds 8 -hydroxy-2-(di- $N$-propylamino) tetralin and ipsapirone in the social interaction paradigm: evidence of a presynaptic action. Brain Res Bull 37:169-175.

Ramboz S, Oosting R, Amara DA, Kung HF, Blier P, Mendelsohn M, Mann JJ, Brunner D, Hen R (1998) Serotonin receptor 1A knockout: an animal model of anxiety-related disorder. Proc Natl Acad Sci USA 95:14476-14481.

Remy SM, Schreiber R, Dalmus M, De Vry J (1996) Somatodendritic $5-\mathrm{HT}_{1 \mathrm{~A}}$ receptors are critically involved in the anxiolytic effects of 8-OH-DPAT. Psychopharmacology 125:89-91.

Riad M, El Mestikawy S, Vergé D, Gozlan H, Hamon M (1991) Visualization and quantification of central $5-\mathrm{HT}_{1 \mathrm{~A}}$ receptors with specific antibodies. Neurochem Int 19:413-423.

Riad M, Watkins KC, Doucet E, Hamon M, Descarries L (1999) 8-OHDPAT internalizes $5-\mathrm{HT}_{1 \mathrm{~A}}$ autoreceptors in serotonin neurons of nucleus raphe dorsalis. Soc Neurosci Abstr 25:1466.

Riad M, Garcia S, Watkins KC, Jodoin N, Doucet E, Langlois X, El Mestikawy S, Hamon M, Descarries L (2000) Somatodendritic localization of $5-\mathrm{HT}_{1 \mathrm{~A}}$ and preterminal axonal localization of $5-\mathrm{HT}_{1 \mathrm{~B}}$ serotonin receptors in adult rat brain. J Comp Neurol 417:181-194.

Rotondo A, Nielsen DA, Nakhai B, Hulihan-Giblin B, Bolos A, Goldman
D (1997) Agonist-promoted down-regulation and functional desensitization in two naturally occurring variants of the human serotonin1A receptor. Neuropsychopharmacology 17:18-26.

Schechter LE, Bolanos FJ, Gozlan H, Lanfumey L, Haj-Dahmane S, Laporte AM, Fattaccini CM, Hamon M (1990) Alterations of central serotoninergic and dopaminergic neurotransmission in rats chronically treated with ipsapirone: biochemical and electrophysiological studies. J Pharmacol Exp Ther 255:1335-1347.

Seth P, Gajendiran M, Ganguly DK (1997) Desensitization of spinal $5-\mathrm{HT}_{1 \mathrm{~A}}$ receptors to $8-\mathrm{OH}-\mathrm{DPAT}$ : an in vivo spinal reflex study. NeuroReport 8:2489-2493.

Sharp T, Bramwell SR, Grahame-Smith DG (1989a) 5-HT1 agonists reduce 5-hydroxytryptamine release in rat hippocampus in vivo as determined by brain microdialysis. Br J Pharmacol 96:283-290.

Sharp T, Bramwell SR, Hjorth S, Grahame-Smith DG (1989b) Pharmacological characterization of 8-OH-DPAT-induced inhibition of rat hippocampal 5-HT release in vivo as measured by microdialysis. Br J Pharmacol 98:989-997.

Sim-Selley LJ, Vogt LJ, Xiao R, Childers SR, Selley DE (2000) Regionspecific changes in $5-\mathrm{HT}_{1 \mathrm{~A}}$ receptor-activated $\mathrm{G}$-proteins in rat brain following chronic buspirone. Eur J Pharmacol 389:147-153.

Smith LM, Peroutka SJ (1986) Differential effects of 5-hydroxytryptamine1a selective drugs on the 5-HT behavioral syndrome. Pharmacol Biochem Behav 24:1513-1519.

Sprouse JS, Aghajanian GK (1986) (-)-Propranolol blocks the inhibition of serotonergic dorsal raphe cell firing by $5-\mathrm{HT}_{1 \mathrm{~A}}$ selective agonists. Eur J Pharmacol 128:295-298.

Sternini C, Spann M, Anton B, Keith Jr DE, Bunnett NW, von Zastrow M, Evans C, Brecha NC (1996) Agonist-selective endocytosis of mu opioid receptor by neurons in vivo. Proc Natl Acad Sci USA 93:9241-9246.

Stockmeier CA, Shapiro LA, Dilley GE, Kolli TN, Friedman L, Rajkowska G (1998) Increase in serotonin-1A autoreceptors in the midbrain of suicide victims with major depression-postmortem evidence for decreased serotonin activity. J Neurosci 18:7394-7401.

Vicentic A, Li Q, Battaglia G, Van de Kar LD (1998) WAY-100635 inhibits 8-OH-DPAT-stimulated oxytocin, ACTH and corticosterone, but not prolactin secretion. Eur J Pharmacol 346:261-266.

Welner SA, de Montigny C, Desroches J, Desjardins P, Suranyi-Cadotte $\mathrm{BE}$ (1989) Autoradiographic quantification of serotonin1A receptors in rat brain following antidepressant drug treatment. Synapse 4:347-352.

Wieland S, Fischette CT, Lucki I (1993) Effect of chronic treatments with tandospirone and imipramine on serotonin-mediated behavioral responses and monoamine receptors. Neuropharmacology 32:561-573.

Willins DL, Berry SA, Alsayegh L, Backstrom JR, Sanders-Bush E, Friedman L, Roth BL (1999) Clozapine and other
5-hydroxytryptamine-2A receptor antagonists alter the subcellular distribution of 5-hydroxytryptamine-2A receptors in vitro and in vivo. Neuroscience 91:599-606. 